DEMOGRAPHIC RESEARCH

VOLUME 37, ARTICLE 26, PAGES 853-866

PUBLISHED 28 SEPTEMBER 2017

http://www.demographic-research.org/Volumes/Vol37/26/

DOI: 10.4054/DemRes.2017.37.26

Editorial

Introduction to the Special Collection on Finding

Work-Life Balance: History, Determinants, and

Consequences of New Breadwinning Models in the Industrialized World

\title{
Trude Lappegård
}

\section{Frances Goldscheider}

\section{Eva Bernhardt}

This publication is part of the Special Collection on "Finding Work-Life Balance: History, Determinants, and Consequences of New Breadwinning Models in the Industrialized World," organized by Guest Editors Trude Lappegård, Frances Goldscheider, and Eva Bernhardt.

(C) 2017 Trude Lappegård, Frances Goldscheider \& Eva Bernhardt.

This open-access work is published under the terms of the Creative Commons Attribution NonCommercial License 2.0 Germany, which permits use, reproduction \& distribution in any medium for non-commercial purposes, provided the original author(s) and source are given credit.

See http:// creativecommons.org/licenses/by-nc/2.0/de/ 


\section{Contents}

$1 \quad$ Background of the special collection $\quad 854$

$1.1 \quad$ Women's entry into the public sphere $\quad 855$

$1.2 \quad$ Men's entry into the tasks of the private sphere 855

2 Contributions to the literature of the special collection 856

$3 \quad$ Content of the special collection $\quad 857$

$3.1 \quad$ The growth and decline of the separate spheres $\quad 857$

$\begin{array}{lll}3.2 & \text { Issues in the new public sphere } & 857\end{array}$

$3.3 \quad$ Issues in the new private sphere $\quad 858$

$4 \quad$ The gender revolution in the public sphere 858

$5 \quad$ The gender revolution in the private sphere $\quad 861$

$6 \quad$ Concluding discussion $\quad 863$

$\begin{array}{ll}\text { References } & 864\end{array}$ 


\title{
Introduction to the Special Collection on Finding Work-Life Balance: History, Determinants, and Consequences of New Breadwinning Models in the Industrialized World
}

\author{
Trude Lappegård ${ }^{1}$ \\ Frances Goldscheider ${ }^{2}$ \\ Eva Bernhardt ${ }^{3}$
}

\begin{abstract}
BACKGROUND

A wide range of new models for breadwinning and caregiving is emerging in the industrialized world. The massive increase in women's labor force participation is bringing many women into the public sphere of men and many men into greater engagement with the private sphere. These are the two halves of the gender revolution, which have challenged the foundations of the concept of the separate spheres, although it is still a powerful model for couples in the $21^{\text {st }}$ century.
\end{abstract}

\section{CONTRIBUTION}

This special collection brings together new knowledge about this ongoing gender revolution, focusing on new models of finding work-life balance. We illuminate the history and determinants of these changes in gendered labor force participation as well as their consequences for how couples organize their economic and family lives. In addition, we relate these changes to the ongoing gender revolution in the public and private spheres, which is transforming the relationships between men and women.

\section{CONCLUSION}

Substantively, the papers in this special collection variously illustrate the tight linkage between the two halves of the gender revolution, with the second half reacting to the changes underway in the first half. The second half is progressing more slowly than the first half, and there is a gap between equal sharing of economic and domestic responsibilities in most countries. Theoretically, the cross-national analyses in particular demonstrate that structural differences - arising from public policies and economic forces that shape couples' choices - are of greater importance than

\footnotetext{
${ }^{1}$ University of Oslo, Norway. E-Mail: trude.lappegard@sosgeo.uio.no.

${ }^{2}$ University of Maryland and Brown University, USA.

${ }^{3}$ Stockholm University, Sweden
} 
ideological differences. And methodologically, the special collection shows the importance of employing a wide range of lenses through which to study such a massive phenomenon, including detailed case studies and multi-level comparative studies.

\section{Background of the special collection}

A wide range of new models for breadwinning and caregiving is emerging in the industrialized world. The five papers included in this special collection are designed to illuminate the history, determinants, and consequences of these new models for how couples organize their economic and family lives. In addition, we want to relate these changes to the ongoing gender revolution in the public and the private spheres that is transforming the relationships between men and women (Goldscheider, Bernhardt, and Lappegård 2015).

For 100 years or so, from the late $19^{\text {th }}$ to the late $20^{\text {th }}$ centuries, the Industrial Revolution was transforming production, applying nonhuman energy to food production and manufacture in vastly more efficient ways than was possible in the agricultural household economies of the past. At the same time, it was transforming the family and the conjugal couple at the core of so many families, as men increasingly left agriculture to take new, more productive industrial and commercial jobs, leaving women and children 'behind' in the home. This divided the family and eventually the gender system into 'separate spheres' - a construct that lasted so long it came to seem eternal, necessary, and foundational. So necessary that the economist Gary Becker (1981) based his theory of the family on the efficiencies of this division of labor and the sociologist Talcott Parsons (1959) did the same. Moreover, numerous followers of Freud accused employed women of being 'unwomanly' (they could not even imagine domestic men) while ascribing a long list of neurotic characteristics to them.

In many ways, the family changes of the past 50 or so years make these theories seem archaic, far removed from our and our children's life experiences. The massive growth in female labor force participation, bringing so many women, especially married mothers, into the public sphere (and even the tentative steps many men have taken into greater engagement with the tasks of the home, the private sphere) have challenged the foundations of the concept of the separate spheres. Nevertheless, few couples, even today, grew up in fully egalitarian homes, and the gender images of the past continue to shape relationships of all kinds, including those underlying the division of the productive and caring tasks necessary for most families. Although still a powerful model for couples in the $21^{\text {st }}$ century, the male-breadwinner/female-caregiver configuration is increasingly being challenged. 


\subsection{Women's entry into the public sphere}

The gender revolution has been described as a twofold process (Goldscheider, Bernhardt, and Lappegård 2015), where the first part is the great increase in female labor market participation. This challenged the traditional breadwinner model, expanding it to include women working part-time while maintaining much of their responsibilities for home and family, and flexible female employment based on mothers' adjusting their employment time to the needs of their families. However, these closely related configurations are also under pressure as women increasingly become more career-oriented.

The growth in female employment since the 1960s precipitates a wide range of pressures. These include internal pressures, e.g., the need for women to be selfsupporting in an environment of rising union dissolution; external pressures, as globalization has flattened so many male incomes; and the pressures provided by the opportunity costs arising from women's greater education, which have increased the costs that result from remaining in the home. Women's opportunities to work have also increased because structural changes in the Western industrialized economies have been favorable to female employment. These opportunities arise from the labor market, with its demand for 'female labor,' from a restructured female life course with smaller families and longer lives, as well as from the public support networks available in many countries, such as subsidized childcare and job guarantees easing the return to (or staying in) the labor force. Moreover, with women's increasingly substantial involvement in paid work outside the home have come pressures on men to contribute more at home.

\subsection{Men's entry into the tasks of the private sphere}

Men's increasing involvement in the private sphere of home and family constitutes the second half of the gender revolution. Men's share of domestic tasks has been increasing since the 1960s (Kan, Sullivan, and Gershuny 2011). In the early decades, most of men's increased share reflected women's declining hours, but in the past several decades men's share has increased because of the growth in their own contributions. Men's entry into the private sphere is not normally the result of as powerful an incentive as that for women's entry into the public sphere (i.e., a salary). However, money has also been a powerful motivation for men to participate in their homes in those countries (and a few US states) that provide paid leave days, especially in cases where a part of the paid leave may only be used by fathers (as an incentive to change the division of labor at home). The lack of such incentives in most countries might 
account for the slow pace of this second half of the gender revolution, although other real pressures have contributed to this phenomenon.

The needs of women's partners and children, of course, are a major source of pressure, but perhaps as part of the growth in "intensive parenting" (Craig, Powell, and Smyth 2014), together with men's own greater interest in the father role (Hofferth and Goldscheider 2015), men have increasingly wanted to become involved in childcare. There are also many pleasures intrinsic to the tasks of domestic life, e.g., working for/with those one cares for and the creative possibilities in home making, like menu planning and cooking, which many men are likely to find more interesting than many industrial/commercial jobs.

As was the case for women's employment, there are still substantial barriers that men face if they want to be more involved in their families. Too many workplaces find ways to punish men who take time off to care for a sick child or cheer a child's athletic performance, and too many other men feel that for a man to do so is letting down their male peers who prefer a traditional masculine role. Many aspects of domestic tasks can be boring, repetitive, and constraining, because meals need to be produced on time and clothes cleaned. And as a mirror image of what helped women enter the public sphere, the private sphere provides so few tangible reinforcements, such as a salary, raises, retirement savings plans, or vacation days.

\section{Contributions to the literature of the special collection}

Hence, in most countries the first half of the gender revolution has advanced further than the second half, but the process of men's increasing involvement in family work is on its way in many countries (Kan, Sullivan, and Gershuny 2011; Altintas and Sullivan 2017). However, although the first half of the gender revolution is not completed in any country, not even in the Nordic countries with their high proportion of women with continuous work lives, it has made far more progress than the second half of the gender revolution (Frejka, Goldscheider, and Lappegård 2017). This means that in most countries there is a significant gap between equal sharing of economic responsibilities in the public sphere and equal sharing of domestic duties and childcare in the private sphere. Women's taking on a "second shift" (Hochschild and Machung 1989) in the first half of the gender revolution may have resulted in a weakening of the family and of couple relationships, while the men taking on a more active role in their families and sharing the responsibilities of care of the children and home is likely to strengthen the family (Goldscheider, Bernhardt, and Lappegård 2015).

Increasingly, both adult men and women expect to participate in employment and in care, as well as to have time for leisure, friends, and family life (Hobson 2014). 
Survey data shows that the majority of women and men in industrialized countries maintain that work-life balance is a main priority when considering their choice of work or workplace (Fahlén 2014). Although there may not be a precise definition of 'work-life balance' (Guest 2002), this concept has generated substantial research in recent years (see, for example, O'Brien and Wall 2017). Whether authors explicitly refer to this concept or not, the papers in this special collection on new breadwinning models in the industrialized world contribute to this general research area.

With this special collection we aim to bring together new knowledge about the ongoing gender revolution in the public and private spheres, focusing on new models for breadwinning and caregiving. When studying gender changes, one often focuses on specific changes, missing the larger picture. A legitimate question is whether the processes that are occurring are uniform, with countries merely proceeding at different paces, or whether countries follow different paths as the separate spheres have changed (Stanfors and Goldscheider 2017). The special collection offers a long-term perspective on the growth and decline of the two separate spheres in two countries, giving a broad picture of the changing gender division of family support and care. It also offers a comparative perspective on female-breadwinner families, family migrations, and division of housework in several countries, which allows for a discussion of the changes in relation to contextual differences.

\section{Content of the special collection}

\subsection{The growth and decline of the separate spheres}

Taken together, the five papers in this special collection provide a thorough discussion of different aspects of the changes in the public and the private spheres accompanying the gender revolution. Stanfors and Goldscheider (2017, SC20-2) give a long-term perspective on women's increasing involvement in paid activity, together with the men's increasing participation in the private sphere, paying special attention to developments in Sweden and the United States.

\subsection{Issues in the new public sphere}

The next section expands the study of women's inclusion in the public sphere by also considering the increase in female-breadwinner families and the implications of having two breadwinners in family for employment-driven migration decisions. Focusing on the period after the Great Recession (around 2010), Vitali and Arpino (2016, SC20-3) 
bring to our attention a relatively new phenomenon in Europe, female-breadwinner families, as their article discusses the influence of context on partners' relative contribution to household income across Europe. Revisiting the issue of family migration being lower among dual-earner couples than among male-breadwinner couples, Vidal, Perales, Lersch, and Brandén (2017, SC20-4) offer a new theoretical framework focusing on contextual factors to understand why and to what extent these two family types differ in their migration propensities, examining the differences among four different countries.

\subsection{Issues in the new private sphere}

This special collection also addresses different aspects of the changes in the private sphere. With a broad European perspective, Fahlén (2016, SC20-5) examines the division of housework among various couple earner types and the influence of contextual factors. With a case study of Sweden, Ruppanner, Bernhardt, and Brandén (2017, SC20-6) provide new insights into the remaining imbalances in the most genderequal country in the world that are linked to the so-called fairness paradox (Ahrne and Roman 1997), whereby unequal divisions of housework are evaluated as fair.

In the following sections, we will discuss the articles in greater depth in light of the gender revolution that is evolving in the public and private spheres.

\section{The gender revolution in the public sphere}

Women taking an active role in the public sphere is indeed increasing across countries in the industrialized world, and the male-breadwinner/female-homemaker model is declining. Still, a family model in which the man is the main provider of family income is very influential across Europe, even in countries that score high on gender equality and women's labor market participation (Vitali and Arpino 2016, SC20-3). Three articles in this special collection address different aspects of this development. What are the main contextual drivers behind women's increasing involvement in the labor market? What are the main contextual drivers behind emerging female-breadwinner couples? To what extent can contextual factors explain family migration rates that are lower among dual-earner couples than they are among male-breadwinner couples? Below we discuss each of these questions in more detail.

Stanfors and Goldscheider (2017, SC20-2) examine the determinants of women's increasing involvement in paid activity in Sweden and the United States. Using long time series of macro-level demographic and economic indicators from the United States 
and Sweden, they examine similarities and differences in depth. The separate-spheres model, that is, the male-breadwinner/female-caregiver configuration, reached its peak around 1950. They argue that at that time married women mainly had reproductive responsibilities; there was social stigma attached to their working outside the home as it indicated having an unsuccessful husband. Three economic and social changes are considered as drivers behind the increase in married women's labor force participation: improving wages, declining fertility, and gains in life expectancy. During the $20^{\text {th }}$ century the real wages as well as female-to-male relative wages increased. In times when the gender pay gap decreased, there was also a high demand for (female) labor (Chichilnisky 2008). Moreover, during the $20^{\text {th }}$ century fertility declined dramatically; where women had previously spent a substantial portion of their adulthood raising children, they were now having only around two children. In addition, dramatic gains in life expectancy have given women many more healthy adult years before or after their childraising commitments.

With women becoming increasingly involved in paid work outside the home, new breadwinning models have emerged. One can distinguish broadly among three main couple-earner models: male-breadwinner, female-breadwinner, and equal-income couples. The female-breadwinner model is a small-scale and relatively new phenomenon in Europe, but its challenge to the traditional economic dominance of men makes it an interesting phenomenon. According to Vitali and Arpino (2016, SC20-3) the prevalence of female-breadwinner families averages around $12 \%$ across the European countries in their study, but with considerable variations across countries (from 22\% in Cyprus to 9\% in Switzerland) as well as within countries. Taking a multilevel approach, the authors bring in several contextual perspectives to examine the determinants of this couple type. They emphasize two main contextual factors in their analysis of partners' economic contribution within the household: societal genderegalitarian attitudes and economic necessity due to unemployment. On the one hand, they argue that female-breadwinner families and equal-earner couples could be driven by gender equality, which would be more widespread in regions with a high prevalence of gender-egalitarian attitudes. On the other hand, they argue that female-breadwinner families and equal-income couples also could be driven by economic necessity in the sense that they may be more widespread in regions with high male unemployment. Using data from the fifth round (2010/2011) of the European Social Survey together with data from the Eurostat database, they provide new important insights into the phenomenon.

First, their results show no positive association between the prevalence of femalebreadwinner couples and the diffusion of gender-egalitarian attitudes, contrary to what was expected. Their results do, however, suggest a higher prevalence of equal-income couples in regions scoring high in terms of gender equality such as Scandinavia, 
Ireland, Estonia, Eastern Germany, and parts of Spain, France, and the United Kingdom. Second, the prevalence of female-breadwinner couples is positively associated with male unemployment. Vitali and Arpino argue that female-breadwinner couples became more common during the recession because of economic necessity and the business cycle, not necessarily by genuine choice.

The industrial revolution, which according to Ruggles (2015) was responsible for demographic changes in family composition, divorce, and marriage, appears to also provide an explanation for the observed prevalence of female-breadwinner couples. In other words, changes in the labor market that have affected men's and women's economic prospects provide a better explanation of the observed pattern of women's economic superiority with respect to their partners than the diffusion of genderegalitarian attitudes, but equal-income couples are more common in countries where gender-egalitarian attitudes dominate.

Finding the perfect job can be challenging, finding two jobs even more so - it comes as no surprise that dual-earner couples have lower migration rates than malebreadwinner couples. But how much lower are they? Where differences are small between the two earner types, it suggests that even in dual-earner couples, one job (and most likely the man's) is taking precedence, so that couples move to improve his financial prospects, forcing women to get a new job in an area that might not offer as many opportunities as were available in the previous location. Vidal et al. (2017, SC204) revisit the issue of family migration and the importance of couple employment. They argue for the need to bring in a theoretical framework that takes into account the national levels of support for female employment and normative expectations about gender roles to act as moderators of the relationship between couple type (i.e., dualearner and male-breadwinner model) and family migration.

Using harmonized data for Australia, Britain, Germany, and Sweden for the period 1992-2011 and appropriate methods, their results corroborate earlier findings that dualearner couples are less mobile than male-breadwinner couples are. They find support for the argument that small differences between male-breadwinner and dual-earner couples are more likely to exist in countries with limited support for female employment and strong traditional gender norms, which is the case in Australia, Britain, and Germany. They also find support for the argument that large differences between the two couple-earner types are more likely to be evident in countries with high support for female employment and stronger egalitarian norms. Indeed, their results show large differences in Sweden, suggesting more gender-equal family migration in genderegalitarian contexts. However, more equity in decisions about family migration does come at the expense of the levels of family migration as finding jobs benefiting two work careers is challenging. The findings of Vidal et al. suggest that the (gendered) 
opportunity context in which family migration decisions are made plays an important role in determining the conditions under which family migration occurs.

\section{The gender revolution in the private sphere}

That dual-earner families are emerging throughout Europe raises questions about how couples are handling the division of housework in different contexts and about their perceptions of fairness vis-à-vis how housework is shared. In many countries men are now taking on a more significant role in housework and childcare; nevertheless, most women are still doing the lion's share, and much of the early change has been because of women decreasing their time spent on domestic responsibilities more than men becoming more involved in housework tasks and childcare (Fahlén 2016, SC20-5). Three articles in this special collection address different aspects of the gender revolution in the private sphere.

Stanfors and Goldscheider (2017, SC20-2) demonstrate that the unraveling of the separate spheres began with the increase in married women's labor force participation and continues with the increase in men's involvement with their homes and children, but its foundations were laid in the $19^{\text {th }}$ century, with industrialization. They show that despite short-term stalls, slowdowns, and even reversals, as well as huge differences in policy contexts, the overall picture of increasing gender sharing in family support and care is strongly taking shape in both the United States and Sweden.

To understand the trends in men's and women's share of domestic tasks, it is necessary to distinguish between housework and childcare and between what was happening separately to women's and men's time, and sometimes even when time is measured (weekday hours vs. weekend hours). The early growth in men's share of domestic tasks in the United States (data before 1990 is not available for Sweden) was driven by women's decreasing housework hours, with little change in their childcare hours (because of the growth in 'intensive parenting'); men's total hours did not actually increase by much. In the late $20^{\text {th }}$ century and early $21^{\text {st }}$ century, however, men have greatly increased their childcare time (especially on weekends). As has been shown for Sweden in recent decades, men's increase in childcare time leads to an increase in their involvement in housework (Evertsson 2014).

In her article, Fahlén (2016, SC20-5) examines the division of housework among couples practicing different breadwinning models in different institutional contexts. Using data from the European Social Survey 2010/2011 for ten countries, she studies couples living in different welfare regimes. Her categorization of couples is twodimensional: She determines whether the partners in a couple are working or not and whether or not they are working in managerial/ professional positions (dual-career 
couple) or not (dual-earner couple). The results show that dual-career couples are likely to share housework more equally than dual-earner couples do. The results also show that even when controlling for time availability, relative resources, gender ideology, family structure, and country differences, there are still differences in men's share of housework between these two different couple-earner types. Interestingly, not only is partners' work status relevant for understanding how couples share housework tasks, but their occupational position in the labor market also plays a role. The main finding is that couple-earner type differences in men's share of total housework are mostly a result of how much time their partner spends on housework. The gender differences in housework among different couple-earner types are present in all countries, but with large variations. For instance, men in dual-earner couples in countries with policies supporting work-family reconciliation do a larger share of housework than other men do. In addition, there are sharp gender differences in housework in countries where gender norms are more traditional. A gender revolution in the private sphere is emerging, but at a very different pace across Europe; policies promoting work-family reconciliation are instrumental in shaping differences in the division of housework.

In particular, the Nordic countries are often characterized as more advanced in gender equality than other countries, reflecting policies encouraging gender-equal responsibilities in economic and domestic duties. Nevertheless, although gender equality is highly normative for both the public sphere and the private sphere, tasks of the private sphere in particular are often not equally shared. Starting from what has been described as a fairness paradox, where an unequal division of housework is evaluated as fair, Ruppanner, Bernhardt, and Brandén (2017, SC20-6) explore the relationship between the division of housework and the perception of how fair this division is in Sweden. They argue that these factors in combination reflect different types of couples. Using Swedish survey data from 2009 and latent class analysis, they identify six distinct types of couples. Although not the majority, the largest group $(33 \%)$ consists of couples that share housework more or less equally and consider this division to be fair. A relatively large group (25\%) consists of couples reporting a semiequal division of housework and the partners disagree about the fairness of this division: While the man considers the division to be fair, the woman thinks it is unfair. Moreover, $36 \%$ of the couples report a traditional or semi-traditional division of housework, where he does less than $40 \%$ of household tasks, but there are different perceptions of fairness. In the same way as Fahlén (2016, SC20-5), Ruppanner, Bernhardt, and Brandén (2017, SC20-6) suggest that institutional policies encouraging gender equality influence couples' perception of the allocation of housework positively. An unexpected finding was the generational divide: Swedish women who witnessed housework inequality in their parental home are more dissatisfied than other women when this inequality repeats itself in their own lives. 


\section{Concluding discussion}

This special collection includes five papers on the causes and consequences of the unraveling of the separate spheres, which have for so long divided the productive activities of men and women into paid workers and family carers. One paper (Stanfors and Goldscheider 2017, SC20-2) provides both a broad and historically long view of the emergence and unraveling of the separate spheres in Sweden and the United States. Two focus on some of the implications/consequences for public sphere family issues: female breadwinners (Vitali and Arpino 2016, SC20-3) and family migration (Vidal et al. 2016, SC20-4). Another two papers focus on some of the implications/consequences for private-sphere issues, i.e., how national characteristics and couple job types shape the division of household labor in a wide range of countries (controlling for couple education) (Fahlén 2016, SC20-5), and how Swedish couples react to the 'fairness paradox' (Ruppanner, Bernhardt, and Brandén 2017, SC20-6).

Taken together, these five papers illuminate substantive theoretical and methodological issues. They illustrate in a variety of ways the tight linkage between the two halves of the gender revolution, with the second half reacting to the changes underway in the first half. The second half is progressing more slowly than the first half, and there is a gap between equal sharing of economic and domestic responsibilities in most countries. Theoretically, the cross-national analyses in particular underline the greater importance of structural differences as opposed to ideological differences. And methodologically, they show the importance of employing a wide range of lenses through which to study such a massive phenomenon - this special collection brings together a contribution from a detailed case study, three multi-level comparative studies, and one detailed comparison of two case studies.

These results raise many questions and challenges for future research. More analyses of change are needed. Would such studies show a continued explosion of family and support strategies and family forms like those that have characterized the past half century? Would they show stability? Or even some evidence of convergence around one or more of these work-family models? Further, more work needs to take into account the increased family complexity underway. Although in some ways, the growing ranks of single parents present a simpler breadwinning/caring model (generally, one person is responsible for both), couple-based families encounter additional complexities when challenged by the uncertainties of cohabitation and the imbalances of stepfamilies. These five studies represent important and useful models to employ in addressing these complexities. 


\section{References}

Ahrne, G. and Roman, C. (1997). Hemmet, barnen och makten: förhandlingar om arbete och pengar i familjen [The Home, the Children, and the Power: Negotiations about Work and Money in the Family]. Stockholm: Fritze.

Altintas, E. and Sullivan, O. (2017). Trends in fathers' contribution to housework and childcare under different welfare regimes. Social Politics 24(1): 81-108. doi:10.1093/sp/jxw007.

Becker, G. (1981). A treatise on the family. Cambridge: Harvard University Press.

Chichilnisky, G. (2008). The gender gap. Review of Development Economics 12(4): 828-844. doi:10.4324/9780203927694.ch4.

Craig, L., Powell, A., and Smyth, C. (2014). Towards intensive parenting? Changes in the composition and determinants of mothers' and fathers' time with children 1992-2006. The British Journal of Sociology 65(3): 555-579. doi:10.1111/14684446.12035 .

Evertsson, M. (2014). Gender ideology and the sharing of housework and child care in Sweden. Journal of Family Issues 35(7): 927-949. doi:10.1177/0192513X14 522239 .

Fahlén, S. (2014). The agency gap: policies, norms, and working time capabilities across welfare states. Chapter 2 in: Hobson, B. (ed.). Worklife balance: The agency and capabilities gap. Oxford: Oxford University Press.

Fahlén, S. (2016). Equality at home - A question of career? Housework, norms, and policies in a European comparative perspective. Demographic Research 35(48): 1411-1440. doi:10.4054/DemRes.2016.35.48.

Frejka, T., Goldscheider, F., and Lappegård, T. (2017). The two-part gender revolution: Women's second shift and changing cohort fertility. [Unpublished manuscript].

Goldscheider, F., Bernhardt, E., and Lappegård, T. (2015).The gender revolution: Understanding changing family and demographic behavior. Population and Development Review 41(2): 207-240. doi:10.1111/j.1728-4457.2015.00045.x.

Guest, D.E. (2002). Perspectives on the study of work-life balance. Symposium: "Work-life balance." Social Science Information 4(2): 255-279. doi:10.1177/ 0539018402041002005. 
Hobson, B. (2014). Introduction: Capabilities and agency for worklife balance - a multidimensional framework. Chapter 1 in: Hobson, B. (ed.). Worklife balance: The agency and capabilities gap. Oxford: Oxford University Press. doi:10.1093/ acprof:oso/9780199681136.003.0001.

Hochschild, A. and Machung, A. (1989). The second shift: Working parents and the revolution at home. New York: Penguin Books.

Hofferth, S. and Goldscheider, F. (2015). Fatherhood. In: Wright, J.D. (editor-in-chief). International Encyclopedia of the Social \& Behavioral Sciences, 2nd edition, Vol 8. Oxford: Elsevier: 840-843. doi:10.1016/B978-0-08-097086-8.31103-5.

Kan, M.Y., Sullivan, O., and Gershuny, J. (2011). Gender convergence in domestic work: Discerning the effects of interactional and institutional barriers from largescale data. Sociology 45(2): 234-251. doi:10.1177/0038038510394014.

O'Brien, M. and Wall, K. (eds.) (2017). Comparative perspectives on work-life balance and gender equality: Fathers on leave alone. New York: Springer. doi:10.1007/ 978-3-319-42970-0.

Parsons, T. (1959). The social structure of the family. In: Anshen, R. (ed.). The family: Its function and destiny. New York: Harper and Row: 241-274.

Ruggles, S. (2015). Patriarchy, power, and pay: The transformation of American families, 1800-2015. Demography 52(6): 1797-1823. doi:10.1007/s13524-0150440-z.

Ruppanner, L., Bernhardt, E., and Brandén, M. (2017). Division of housework and his and her view of housework fairness: A typology of Swedish couples. Demographic Research 36(16): 501-524. doi:10.4054/DemRes.2017.36.16.

Stanfors, M. and Goldscheider, F. (2017).The forest and the trees: Industrialization, demographic change, and the ongoing gender revolution in Sweden and the United States, 1870-2010. Demographic Research 36(6): 173-226. doi:10.4054/ DemRes.2017.36.6.

Vidal, S., Perales, F., Lersch, P. M., and Brandén, M. (2017). Family migration in a cross-national perspective: The importance of within-couple employment arrangements in Australia, Britain, Germany, and Sweden. Demographic Research 36(10): 307-338. doi:10.4054/DemRes.2017.36.10.

Vitali, A. and Arpino, B. (2016). Who brings home the bacon? The influence of context on partners' contributions to the household income. Demographic Research 35(41): 1213-1244. doi:10.4054/DemRes.2016.35.41. 
Lappegård, Goldscheider \& Bernhardt: Introduction to the Special Collection on Finding Work-Life Balance 